\title{
811.163.41'367
}

811.163.41'367.626.3

https://doi.org/10.18485/sj.2021.26.1.10

ТАњА 3. РУСИМОВИТ *

Универзитет у Крагујевцу

Институт за информационе технологије
Оригинални научни рад

Примљен: 13. 10. 2020.

Прихваћен: 12. 1. 2021.

\section{ПОКАЗНЕ ЗАМЕНИЦЕ ЗА ИДЕНТИТЕТ КАО КАТАФОРИЧКИ ЕНДОЦЕНТРИЧНИ АНТЕЦЕДЕНТ РЕЛАТИВНЕ КЛАУЗЕ ${ }^{* *}$}

Ендоцентрични антецедент представља интерференцију лексичкосемантичког и формалног антецедента. Под термином ендоцентрични антецедент подразумевамо антецедент који се односи на групу синтаксички повезаних речи, у којој је подређени члан функционално еквивалентан групи, односно супстантиватизиран. Овај антецедент може катафорички или анакатафорички упућивати. У раду издвајамо критеријуме помоћу којих се ендоцентрични антецедент диференцира и од лексичкосемантичког, и од формалног антецедента. Ендоцентрични антецедент је облигаторан и може имати катафоричко упућивање према релативној клаузи у исказима у којима именица која је изостављена из антецедента није експлицирана у контексту.

Кључне речи: релативна адјективна клауза, ендоцентрични антецедент, (не)референцијалнист, (не)одређеност, катафоричка референција, облигаторност.

*tanjarusimovic@yahoo.co.uk

** Рад представља део истраживања које је представљено на Славистичком конгресу у Београду 2018. у виду постера (види: Тезе и резимеи Међународног конгреса слависта, том 1, Језик, Београд, 20-27. 8. 2018, 236-237). 


\section{1. УВОДНЕ НАПОМЕНЕ}

Када се проучава антецедент релативних клауза, истичу се два типа: лексичкосемантички - уз који је уврштена адјективна релативна клауза (пр. На овом месту лежи онај читалац КОЈИ неће никада отворити ову књигу) и формални - који може бити факултативан и уз који је уврштена супстантивна релативна клауза (пр. (Онај) $K O$ рано рани, две среће граби). Овим истраживањем указаћемо на трећи тип антецедента, који представља интерференцију лексичкосемантичког и формалног антецедента (пр. Ономе КОЈИ има способност за трговину, може старешина одобрити да се њоме бави). Антецедент у трећем примеру подсећа на формални (Сњежана Кордић (1995) сматра га формалним), док релативна клауза јесте адјективна као код лексичкосемантичког антецедента. Овај антецедент именовали смо као ендоцентрични антещедент (в. Русимовић 2014: 171-172), он је облигаторан и може имати катафоричко упућивање према релативној клаузи у исказима у којима именица која је изостављена из антецедента није експлицирана у дискурсном контексту, а може имати и анафоричко и катафоричко упућивање, односно, анакатафоричко ${ }^{1}$ уколико је изостављена именица из антецедента експлицирана у дискурсном контексту. У раду анализирамо показне заменице за идентитет у функцији катафоричког ендоцентричног антецедента, а истраживање је спроведено на разнофункционалном корпусу савременог српског језика.

\section{2. ЕНДОЦЕНТРИЧНИ АНТЕЦЕДЕНТ РЕЛАТИВНЕ КЛАУЗЕ}

Под термином ендоцентрични антецедент ${ }^{2}$ подразумевамо антецедент који се односи на групу синтаксички повезаних речи, у којој је подређени члан функционално еквивалентан групи, односно супстантиватизиран (пр. онај човек који $\leftarrow$ онај који; они људи који $\leftarrow$ они који). У таквим ситуацијама употребљена заменица није детерминатор, већ као једини конститутивни члан номиналне синтагме она представља супстантиват и остварује референцију ${ }^{3}$ и синтаксичку функцију читаве номиналне синтагме.

${ }^{1}$ Овим истраживањем неће бити обухваћено анакатафоричко упућивање ендоцентричног антецедента управи због комплексности форичких односа и обима истраживања.

${ }^{2}$ У односу на термин ендоцентричан, како га одређује Кристал (1988: 63), где је управни члан одредиви центар унутар синтагме и има исту дистрибуцију као целина (нпр. онај човек човек) у нашем случају ендоцентрични антецедент представља конституентску јединицу која је супстантиватизирана, те може бити функционално еквивалентна синтагми (нпр. онај човек $\leftarrow$ онај).

${ }^{3}$ Референција представља однос између конкретно употребљене лексеме и неког тачно одређеног ванјезичког ентитета, означеног термином референт. Самостална лексема има само 
Супстантивна функција адјектива резултат је процеса функционалне транспозиије или функиионалног преобразоваға неке синтаксичке категорије речи. На тај начин, адјективна синтаксичка категорија у одређеним лексичко-синтаксичким условима преузима синтаксичку функцију супстантивне категорије речи, али при том не губи своја категоријална својства (в. Ковачевић 2000: 265-267, Курилович 1962: 57-71 и Баји 1955: 130-145). То значи да је сталном садржају заменице додат и садржај преузет од именице познате из контекста, а на тај начин „однос детерминације није експлицитно остварен него је садржан у самом генеративном поријеклу супстантивата" (Ковачевић 2000: 277). Наведе ли се именица, адјективи су атрибути, без именице они су супстантивати „преузимају функцију синтагме с редукованом именицом” (Ковачевић 2000: 268).

Ово елиптирање именице из антецедента омогућено је контекстом. Због тога је форичност антецедента пресудна у постизању одређености референта, а на тај начин и информативности дискурса.

Под дискурсом подразумевамо усмени или писани језик у контексту, али оно што је неодвојиво од дискурса као теоријског појма јесте његова друштвена условљеност, а то је сагледавање језика као „динамичког, социјалног, интерактивног феномена - како између говорника и слушаоца, тако и између писца и читаоца" (Кристал 1987: 116). Нашем одређењу термина дискурс доприноси становиште да текст представља производ, тј. да је искључиво организован као семантичка јединица која чини целину, а да дискурс представља динамичку структуру (Халидеј/Хасан 1976). Другим речима, „дискурс је текст који је могуће успешно интерпретирати уз упућивање на ванјезички контекст" (Русимовић 2014: 50).

\section{1. Катафоричко упућивање ендоцентричног антецедента}

Ендоцентрични антецедент имаће само катафоричко упућивање према релативној клаузи у исказима у којима именица која је изостављена из антецедента није експлицирана у контексту. У ситуацијама када контекст не садржи одговарајућу именицу, онда се на основу садржаја заменице и адјективне клаузе претпоставља именички садржај и он је по правилу општег карактера, тј. обележја су му [+људско] и [+/-једнина], па је зато и изостављен као редундантан (најчешће је претпостављени лексем именица човек/људи). То значи да ендоцентрични антецедент представља најчешће нереференцијални израз. ${ }^{4}$

смисао и денотацију, док се о референцији говори тек уколико је лексема део дискурса (Лајонс 1977: 206).

${ }^{4}$ Референиијалност представља својство језичког знака да индивидуализира неки ентитет, који је узет појединачно или као мноштво истоврсних ентитета из класе којој он припада, 


\title{
2.1.1. Нереференцијалност катафоричког ендоцентричног антецедента
}

\author{
Показне заменице за идентитет су најфреквентније у улози катафоричког \\ ендоцентричног антецедента:
}

(1) Ономе КОЈИ има способност за трговину може старешина одобрити да се њоме бави (Ј. Цвијић, 19). Оне то увек ураде са оним у КОГА не сумњаш (Д. Ћосић, 127). - па већ тада, када је дакле било најгоре и најтеже, већ је тада она била уверена да никада, никада неће бити тога, неће се родити тај КОЈИ би био раван и достојан ње; достојан и њене оволике лепоте а и саме ње као Софке .ефенди-Митине” (Станковић,

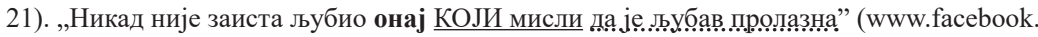
com/pages/./293282026017). Није богат онај КОЈИ има највише - већ онај КОМЕ треба најмање (www.demotivacija.rs/ 21810.html 5 апр 2012). Онај КОЈИ мрзи, бива поједен мржњом ( facebookreporter.org/ 27 јан 2012 ). Да ли онај ШТО је убио човека мора умрети или не мора (siont.net > Biblija > Članci > Odgovori na poteškoće)? Луд је само онај ЧИЈА ce лудост не поклапа са лудошћу већине (www.pravaideja.com/prica.php?q=200 / 5 јан 2012). Онај ЧИЈА је мудрост обилнија од његових дела, коме је сличан (www.biblija.rs/pages/ biblija_jevrejska_poredjenja.html).

Најпре, реконструишемо форичност ендоцентричног антецедента:

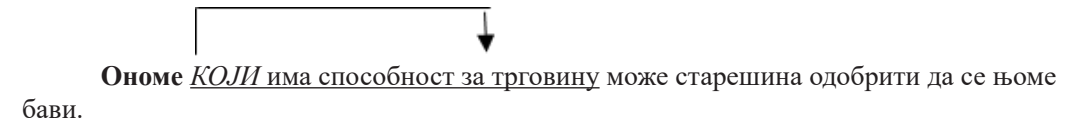

Дакле, ендоцентрични антецедент у примерима (1) подразумева лексему човек која у оваквој употреби представља нереференцијални израз (било који човек). Реконструишемо први пример тако што експлицирамо ову лексему у антецеденту. Лексему човек могуће је претпоставити на основу садржаја пре свега надређене клаузе (човеку се може дати одобрење да се трговином бави), али и на основу садржаја релативне клаузе (само човек може имати способност за трговину).

[ $\leftarrow$ Ономе човеку КОЈИ има способност за трговину може старешина одобрити да се њоме бави.]

Поставља се питање да ли је у примерима са оваквим антецедентом

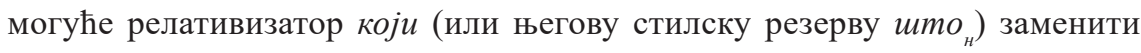
релативизатором ко:

тј. могућност за локализацију ентитета у односу на време, место и учеснике говорне ситуације. На тај начин „референцијалност омогућује актуелизовање пропозиционог садржаја реченице, односно појединих њених делова, путем којег се реченица претвара у исказ и преводи из језика у говор" (Пипер 2005: 915). Нереференцијалност ће онда представљати одсуство референцијалне употребе језичког знака. То су ситуације када се језички знак односи на нешто што је једна од више могућности, тј. нешто што је потенцијално, фиктивно, а не представља издвојени део ситуације означене исказом у којем је тај знак употребљен. То би биле неспецифичне интерпретације у значењу било који, било ко, ма који, ма ко, икоји, ико, који год, какав год, колико год, ко год. 

бави.]

[ŁОноме $K O$ има способност за трговину може старешина одобрити да се њоме

Реконструкција је показала да је без икаквих семантичких последица могуће у оваквим исказима релативизатор који супституисати релативизатором ко. Међутим, на синтаксичком плану антецедент онај уз релативизатор који представља ендоцентрични антецедент, док антецедент онај уз релативизатор ко представља формални антецедент (види поглавље Формални антецедент релативне клаузе уврштене релативизаторима ко и што, Русимовић: 2014).

Пошто релативизатор ко не може имати именицу и личну заменицу за свој антецедент, анализираћемо када се без последица може употребити уместо релативизатора који и што :

Пример а: Нека дође онај који зна пливати што зна пливати ко зна пливати

Пример a1: Нека дођу они који знају пливати што знају пливати *ко знају пливати онај човек који зна пливати што зна пливати

* ко зна пливати

/ ониљуди којизнајупливати што знају пливати *ко знају пливати

Дакле, могуће је синонимно употребити варијанте онај који и онај ко. У досадашњој литератури полази се од чињенице да је за реченице са релативизатором ко својствено да се односе на референт који је хипотетичан, по томе се „израз онај тко разликује од израза онај који - док се први израз односи само на потенцијалну или хипотетичну особу, дотле се други израз, иако се може односити и на такву особу, првенствено односи на издвојену, конкретну особу" (Кордић 1995: 208). С друге стране, Жуљевић након детаљне анализе не негира претходни став, али истиче „да се не може увијек повући оштра граница између зависних релативних реченица уз показне заменице (у мушкоме роду једнине) у зависности од тога да ли је релатив који или (m) ко" (1992: 227). Полазећи од става Ковачевића да релативизатор који уводи искључиво присупстантивне клаузе, који је „основни релативизатор структурно нерашчлањене сложене реченице са релативном зависном клаузом" (1998: 224) сматрамо да питање да ли антецедент у изразу онај који можемо сматрати формалним антецедентом представља структурално питање. На овом нивоу анализе релевантно је да релативизатор ко својом сталном семантиком да се односи на ентитет који има својство [+живо] и [+људско] недвосмислено упућује само на антецедент који подразумева лексему човек у нереференцијалном значењу. Стална семантика релативизатора ко је толико јака да је антецедент, обавезно формални, често факултативан, што зависи од његове функције граматичког субјекта у надређеној клаузи. Када је факултативан, формални антецедент је најчешће неексплициран. Међутим, релативизатор који упућује на ендоцентрични антецедент који је облигаторан, односно не- 
испустив. Овај антецедент подразумева нереференцијални израз човек, али поред лексеме човек, могу се у антецеденту подразумевати и друге лексеме с обележјима [+живо] и [+људско], те показна заменица за идентитет као ендоцентрични антецедент јесте издиференцирана граматичким категоријама рода и броја (осим онај, фреквентни су и облици она, оно; они, оне, она). Која ће се лексема подразумевати у антецеденту, сугерише непосредни дискурсни контекст, односно, надређена и релативна клауза.

Иако су у корпусу најфреквентнији примери са подразумеваном лексемом човек, своју фреквенцију имају и искази у којима се подразумева лексема љьуди:

(2) Што је још горе, када се инфаркт деси, мало је оних КОJИ препознају све његове знаке и симптоме и већина није ни свесна шта се догодило (НИН; 26.02.2009. бр. 3035, 27). Њега су запослиле две поменуте аустралијске фирме да саветује људе повређене у аутомобилским несрећама, као и оне $К О Ј И$ су имали проблема на радном месту (Курир 29.09.2011.24). О мени се најлепше брину они КОЈИ ме остављају на миру (miki-i-ostalim-cudima.blogspot.com./14.3.12).

Реконструишемо први пример из групе (2):

[ŁШто је још горе, када се инфаркт деси, мало је оних људи КОЈИ препознају све његове знаке и симптоме и већина није ни свесна шта се догодило.]

Ретко, и то увек када је потребно истаћи само женски род јер садржај релативне или надређене клаузе то захтева, у антецеденту је могуће подразумевати и лексему жена:

(3) Пред Богом су нероткиње грешне, а не оне ШTO рађају држави војнике и Богу вернике (Д. Ћосић, 109). [־Пред Богом су нероткиње грешне, а не оне жене ШТО рађају држави војнике и Богу вернике.]

Подразумеване лексеме људи, жена/жене у антецеденту представљају такође нереференцијалне изразе, међутим, уз овакве ендоцентричне антецеденте они и оне није могуће супституисати релативизатор који релативизатором ко:

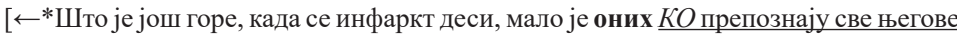
знаке и симптоме и већина није ни свесна шта се догодило.] вернике.]

[ ${ }^{*}$ Пред Богом су нероткиње грешне, а не оне $K O$ рађају држави војнике и Богу

Анализа је показала да су семантички синонимне једино конструкције онај који и онај ко. Такође, можемо рећи да ендоцентрични антецедент има шири спектар употребе баш због могућности диференцирања граматичким категоријама рода и броја.

Показна заменица онај често чини низ са неком другом заменицом у антецеденту и то најчешће са општом заменицом, те катафорички упућују, односно, представљају нереференцијани израз:

(4) Дугих очију и равних истурених уста, изненаде све оне КОЈИ су икада волели египатске уметности (Р. Петровић, 86). За све оне КОЈИ пију кафу широм света 1. октобар је важан датум већ дуги низ година (Прес 29.09.2011, 33). Тачно је одређено за свакога 
од њих на КОЈИ се начин има мислити и делати (Ј. Цвијић, 20). Тадић је објаснио да Србија у међународној заједници рачуна на све оне КОJИ су привржени поштовању међународног права, а да ће оне, КОJИ не деле њено мишљење, покушати да убеди дипломатским и политичким средствима (Политика 13.09.2011, 7).

У примерима (4) катафоричко упућивање везана је за показну заменицу, јер је деиктичка природа њој примарна, док у овој позицији својом сталном семантиком општа заменица представља интензификатор.

\subsection{2. Неодређени референцијални катафорични ендоцентрични антецедент}

Навели смо да катафорични ендоцентрични антецедент најчешће представља нереференцијални израз, но могуће је издвојити примере са референцијалним изразом. Под референцијалном употребом ${ }^{5}$ подразумевамо ситуације када је ентитет контекстуално одређен ${ }^{6}$, било да је претходно поменут, било да је учесницима у комуникацији познат на основу њиховог знања о ванјезичкој стварности, или пак може бити нов у дискурсу, те самим тим неодређен и непознат говорнику и/или саговорнику. Категорија одређеност/неодређеност на тај начин показује „да се извесна језичка информација, садржана у реченици или у неком њеном делу, пореди с менталним искуством учесника у комуникацији и квалификује се као нешто што је већ локализовано у њиховом менталном искуству - одређеност - или се налази изван њиховог менталног искуства - неодређеност” (Пипер 2005: 918).

Како референцијални изрази могу бити одређени и неодређени, то значи да и ендоцентрични антецедент, спецификован адјективном клаузом, може подразумевати референцијални израз. Када ендоцентрични антецедент представља референцијални израз и након катафоричког упућивања према релативној клаузи, референт у антецеденту остаје неодређен:

(5) Софка отвори капију и стаде ишчекујући да уђе тај КОJИ лупа (Б. Станковић, 29). Сад је сигурнији да је тај ШТО је пуцао на краља био у договору са Аћимом (Д.

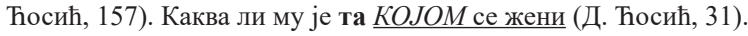

${ }^{5} \mathrm{У}$ нереференцијалним употребама немогуће је говорити о познатости или непознатости денотата именског израза, „будући да у овом типу употреба референт није неки индивидуализован, односно просторно-временски делимитиран ентитет, који би се евентуално могао идентификовати" (Станојевић 2010: 124-125). Зато и сматрамо да када имамо нереференцијалну употребу именског израза говоримо у ствари о денотату.

${ }^{6}$ Када је о одређености реч, треба поменути да сербокроатистичка традиционална литература одређеност поима као познатост, поменутост у претходном тексту (Миклошић 1883, Белић 1958, Стевановић 1950/1991, Маретић 1963, Фекете 1969/73, Пипер 2005). Дакле, лингвистичка категорија одређености третира се као еквивалентна когнитивној категорији познатости. 
У примерима (5) на основу садржаја надређене клаузе, односно, због референцијалности израза у њеном предикату (уће, био у договору, каква је) неминовно је да је израз референцијалан и у антецеденту. Референцијалност ендоцентричног антецедента потврђује и садржај релативних клауза, пре свега глагол у предикату (луnа, је пуцао, се жени). То значи да мора представљати референцијални израз онај који се квалификативно може одредити (онај који лупа и улази, онај који је пуцао и који је у договору, она којом се жени). За део дискурса којем припадају ови искази није релевантна одређеност референцијалних ендоцентричних антецедената. Неодређеност може остати трајна на нивоу целог дискурса, али се може постићи одређеност трансфрастичким ендофоричким упућивањем са даљим дометом у дискурсу. Наравно, оба поступка су у вези са онеобичавањем исказа и појачавањем ишчекивања читалаца, пошто је у свим случајевима реч о књижевноуметничком стилу.

Неодређеност може остати трајна и у исказима разговорног стила (нпр.

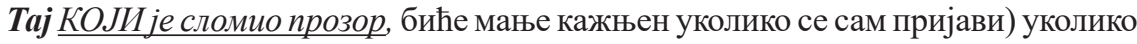
се никада не открије починилац.

(6) „Молимо оне КОЈИ одлучују о судбини ових људи да укључе целу Србију у решавање ових проблема, да то не решавају ноћу иза затворених врата, да не држе у недоумици и рањене и оне који их лече и оних који их обилазе", истакао је он (Курир 29.09.2011. 42). Они КОЈИ су подржали насилне потезе Приштине хтели су да изолују Србију и покажу да Београд није за договор, а Србија је спремна за договор било кад и било где - каже Стефановић (Курир 29.09.2011. 25). Сведок сарадник: Прете ми они КОЈИ треба да ме чувају (Блиц 25 јан 2012, 14). Закон пишу они КОЈИ су компетентни да доносе политичке одлуке (www.dnevnik.rs/.../zakon-pisu-oni-koji-su-kompetentni). А што тај КОЈИ је одредио илити прогласио да су ово опасни пси није досао на протест, па да сам процени да ли су то стварно опасни пси (www.24sata.rs/vesti/beograd/vest) protest...da.../35768.phtml 7 апр 2012). Тог КОГ сам искрено волела није знао то да цени (lajkujem.com/status/528211).

И примери (6) илуструју употребу референцијалног ендоцентричног антецедента који остаје неодређен и након катафоричког упућивања на релативну клаузу. Заменица онај употребљена је у множини, што значи да подразумева лексему људи, док заменица тај подразумева именицу човек у антецеденту. Релативном адјективном клаузом издвојен подскуп ентитета може бити одређен комуникаторима на основу ванјезичке стварности и заједничког знања који комуникатори деле (онда би имали и егзофоричку референцију), али уколико то није релевантно, остаће неодређено-референцијални израз само са катафоричким упућивањем. Овакви примери карактеристика су публицистичког и разговорног стила.

Дакле, катафоричко упућивање имаће неодређено-референцијални ендоцентрични антецедент уколико одређеност није ни релевантна надређеној клаузи, тако да иако се може егзофорички реферирати, егзофора ипак изостаје. У корпусу смо издвојили само показне заменице у функцији неодређеног 
референцијалног ендоцентричног антецедента који може само катафорички упућивати.

\section{3. ЗАКљУЧАК}

Ендоцентрични антецедент представља антецедент који се односи на групу синтаксички повезаних речи, у којој је подређени члан функционално еквивалентан групи, односно супстантиватизиран. Овај антецедент може катафорички или анакатафорички упућивати. Уколико је реч о нереференцијалном или о неодређеном референцијалном ендоцентричном антецеденту, онда је актуелно само катафоричко упућивање према адјективној клаузи, а подразумевана лексема није експлицирана у дискурсу.

Анализа је показала да ће ендоцентрични антецедент имати само катафоричко упућивање према релативној клаузи у исказима у којима именица која је изостављена из антецедента није експлицирана у непосредном дискурсном контексту. У ситуацијама када дискурсни контекст не садржи одговарајућу именицу, онда се на основу садржаја заменице и адјективне клаузе претпоставља именички садржај и он је по правилу општег карактера, тј. обележја су му [+људско] и [+/-једнина], па је зато и изостављен као редундантан. Да би овако описани ендоцентрични антецедент могао само катафорички упућивати према релативној клаузи, морају бити задовољени следећи услови:

Ендоцентрични антецедент мора подразумевати лексему човек/људи и у одређеним околностима жена /жене, дете/деца.

Ендоцентрични антецедент најчешће представља нереференцијални израз (било који човек/људи, било која жена/деца, било које жене/дете).

Уколико ендоцентрични израз представља неодређени референцијални израз, он остаје неодређен и као такав релевантан надређеној клаузи.

Ендоцентрични антецедент има широки спектар употребе, што се тиче изнијансираности у вези са категоријом граматичког рода и броја. Једино када је у мушком роду једнине, представља синтаксички синонимну конструкцију са конструкцијом формални антецедент + релативна клауза уврштена релативизатором ко. Стална семантика релативизатора ко је толико јака да је антецедент, обавезно формални, често факултативан, што је у вези са функцијом граматичког субјекта у надређеној клаузи. Када је факултативан, формални антецедент је најчешће неексплициран. На другој страни, релативизатор који упућује на ендоцентрични антецедент који је облигаторан, односно неиспустив. Која ће се лексема подразумевати у антецеденту, сугерише непосредни дискурсни контекст, односно, садржај надређене и релативне клаузе. 


\section{ИЗВОРИ}

Б. Станковић - Борисав Станковић, Нечиста крв, www.ask.rs

Р. Петровић - Растко Петровић, Африка, www.ask.rs

Д. Ћосић - Добрица Ћосић, Корени, www.ask.rs

J. Цвијић - Јован Цвијић, Психичке особине Јужних Словена, www.ask.rs Блиц - Блиц, дневне новине из Београда.

Политика - Политика, дневне новине из Београда

НИН - НИН, недељне новине из Београда

Курир - Kurir, dnevne novine iz Beograda

Преc - Press, dnevne novine iz Beograda

www.biblija.rs

www.24sata.rs/vesti

www.dnevnik.rs

miki-i-ostalim-cudima.blogspot.com.

www.facebook.com

www.demotivacija.rs

www.pravaideja.com

www.lajkujme.com

\section{ЛИТЕРАТУРА}

Баји 1955: Ш. Балли, (Charles Balli), Общзая лингвистика и вопросы франиузского языка, Москва: Издательство иностранной литературы.

Белић 1958: А. Белић, О језичкој природи и језичком развитку, књ. І, Београд: Нолит.

Жуљевић 1992: S. Žuljević, Relativne rečenice u njemačkom i srpskohrvatskom jeziku, [doktorska disertacija], Sarajevo: Filozofski fakultet Univerziteta u Sarajevu.

Ковачевић 1998: М. Ковачевић, Синтакса сложене реченице, Београд: Рашка школа.

Ковачевић 2000: М. Ковачевић, Стилистика и граматика стилских фигура, Крагујевац: Кантакузин. 
Кордић 1995: S. Kordić, Relativna rečenica, Znanstvena biblioteka Hrvatskog filološkog društva, 25, Zagreb: Matica hrvatska.

Курилович 1962: Е. Курилович, Очерки по лингвистике, Москва: Издательство иностранной литературы.

Кристал 1987: D. Kristal, Кембричка енциклопедија језика, Београд: Нолит.

Кристал 1988: D. Kristal, Enciklopedijski rečnik moderne lingvistike, Beograd: Zavod za izdavanje udžbenika NR Srbije.

Лајонс 1977: J. Lyons, Semantics, Cambridge: Cambgidge University Press.

Маретић 1963: T. Maretić, Gramatika hrvatskoga ili srpskoga književnog jezika, Zagreb: Matica hrvatska.

Миклошић 1883: F. Miklošić, Vergleichende Sintah der slavischen Sprachen, zwiete Abdruck, Wien.

Пипер и др. 2005: П. Пипер и др, Синтакса савременога српског језика: проста реченииа, Београд, Нови Сад: Институт за српски језик САНУ, Београдска књига, Матица српска.

Русимовић 2014: Т. Русимовић, Релативна реченица са форичким супстантивним антецедентом у савременом српском језику, Крагујевац: Филолошко-уметнички факултет Универзитета у Крагујевцу [докторска дисертација].

Станојевић 2010: В. Станојевић, О неким аспектима референцијалности у француском и у српском језику, у: М. Ковачевић (ред.), Интердисииплинарност и јединство савремене науке, књ. 4, том 1, Пале, Универзитет у Источном Сарајеву, 123-135.

Стевановић 1991: М. Стевановић, Савремени српскохрватски језик, књ. 2: Синтакса, Београд: Научна књига.

Фекете 1969/73: E. Fekete, Oblik, značenje i upotreba određenog i neodređenog pridevskog vida u srpskohrvatskom jeziku, prvi деo u: Južnoslovenski filolog, 28, 1-2, 1969, 321-386; drugi deo u: Južnoslovenski filolog, 29, 3-4, 1973, 339-523.

Халидеј/Хасан 1976: М. A. K. Halliday, R. Hasan, Cohesion in English, London. 


\title{
DEMONSTRATIVE PRONOUNS FOR IDENTITY AS THE CATAPHORIC ENDOCENTRIC ANTECEDENT OF THE RELATIVE CLAUSE
}

\begin{abstract}
Summary
The endocentric antecedent represents the interference of the lexical-semantic and formal antecedent. Under the term of the endocentric antecedent we imply the antecedent referring to a group of syntactically connected words, where the subordinate member is functionally equivalent to the group, i.e. it is substantivised. This antecedent can serve as a cataphoric or anacataphoric reference. The analysis has shown that the endocentric antecedent has only a cataphoric reference to the relative clause in the statements when the noun omitted from the antecedent is not explicated in the discourse. In the situations when the discursive context does not contain the relevant noun, the noun content is assumed based on the content of the pronoun and adjectival clause. As a rule, it is of general character, i.e. its features are [+human] and [+/-singular], which is why it is omitted as redundant. The endocentric antecedent has a wide range of uses, in terms of the nuances of the category of the grammatical gender and number. Only when in masculine singular form does it represent a construction syntactically synonymous with the construction formal antecedent + relative clause introduced by the relativiser who. The endocentric antecedent is obligatory and can have cataphoric reference to the relative clause in statements where the noun omitted from the antecedent is not explicated in the context. The lexeme implied in the antecedent is suggested by the immediate discursive context, i.e. the content of the superordinate and relative clauses.
\end{abstract}

Keywords: relative adjectival clause, endocentric antecedent, non(referentiality), in(determinacy), cataphoric reference, obligatoriness. 